This item was submitted to Loughborough's Research Repository by the author.

Items in Figshare are protected by copyright, with all rights reserved, unless otherwise indicated.

\title{
A sense of belonging helps! The alleviating effect of national identification on burnout among diplomats
}

PLEASE CITE THE PUBLISHED VERSION

https://doi.org/10.1108/JGM-06-2021-0063

PUBLISHER

Emerald

VERSION

AM (Accepted Manuscript)

\section{PUBLISHER STATEMENT}

This paper was accepted for publication in the journal Journal of Global Mobility and the definitive published version is available at https://doi.org/10.1108/JGM-06-2021-0063.

\section{LICENCE}

CC BY-NC 4.0

\section{REPOSITORY RECORD}

Zhang, Ling Eleanor, Jakob Lauring, and Ting Liu. 2021. "A Sense of Belonging Helps! the Alleviating Effect of National Identification on Burnout Among Diplomats". Loughborough University.

https://hdl.handle.net/2134/17126561.v1. 


\title{
A sense of belonging helps! The alleviating effect of national identification on burnout among diplomats
}

\begin{abstract}
Purpose - This paper aims to explore the interplay between burnout, national identity, and career satisfaction among diplomats. In particular, we focus on the roles of home and host country identification as an emotional resource for overcoming the negative effects of job-related burnout. Design/methodology/approach - We use survey responses from 123 diplomats to assess the moderating role of home and host country identification on the relationship between burnout and career satisfaction.

Findings - We tested various combinations of high or low home or host country identification, and our findings suggest that the negative effect of burnout on career satisfaction is reduced for those individuals that have high identification with both the home and the host country, while this is not the case for other combinations. This points to the beneficial effects of dual national identifications even for diplomats - a group that would normally be expected to identify strongly with the home country alone.

Originality/value - No existing study that we know of has explored the relationship between burnout, national identity, and career satisfaction among diplomats or other types of expatriates. This is unfortunate because a better understanding of national identity could guide practitioners in finding ways to reduce the negative consequences of burnout in international organizations.
\end{abstract}

Keywords: diplomat, expatriate, burnout, career satisfaction, home country identification, host country identification 


\section{Introduction}

Levels of burnout are currently found to be alarmingly high among many groups of white-collar workers (Dylag et al., 2013; Willard-Grace et al., 2019). In addition to the detrimental personal consequences for individuals, burnout can contribute to reduced performance (Bakker et al., 2004) and increased turnover due to low satisfaction with career development (Rahim and Cosby, 2016). In this regard, studies reveal that high levels of burnout are particularly prominent among expatriates who spend much of their career outside their home countries (Bhanugopan and Fish, 2006; Silbiger and Pines, 2014; Selmer and Fenner, 2009). Burnout is considered a consequence of strain caused by the need to adjust to novel work conditions and represents a challenging job demand (Silbiger et al., 2017). Interestingly, although burnout is frequently reported by expatriates, not all individuals experience the same negative consequences for work performance and career satisfaction. Influencing factors are, for example, the perceived importance of work (Silbiger and Pines, 2014), the supervisor-subordinate relationship (Yuan et al., 2019), as well as role conflict, role ambiguity, and role overload (Bhanugopan and Fish, 2006).

Our study follows this stream of work, which explores specific contextual factors that can affect the consequences of expatriate burnout and alleviate negative effects on the performance and career outcomes of expatriates (e.g., Silbiger and Pines, 2014). We focus specifically on the role of expatriates' home and host country identification. There is increasing consciousness of national identity as a consequence of globalization and the dynamics of international relations (Horak et al., 2019; Reade, 2001). At the same time, national identity has become more complex due to increased migration flows and global work mobility (Fleischmann and Phalet, 2018). While the literature on expatriation has traditionally emphasized the importance of recognizing home and host country identification of expatriates (Leonardelli and Toh, 2011; Varma et al., 2011), little empirical work has been conducted to examine its actual consequences. To obtain knowledge of this research gap, we investigated the issues of national identity and burnout among an extreme type of expatriates in terms of host country identification - namely diplomatic expatriates.

Diplomatic expatriates ${ }^{1}$ take on one international assignment after another and experience health-related challenges such as stress and burnout that are rarely addressed in empirical studies (Brandt and Buck, 2005; Fliege et al., 2016). There is a lack of knowledge on the effect of national

\footnotetext{
${ }^{1}$ In this paper, we use the term "diplomats" and "diplomatic expatriates" interchangeably, treating diplomats as one type of expatriates in keeping with previous studies (e.g. Fliege et al., 2016).
} 
identity, which is of particular relevance to diplomats during their repeated expatriations to various host countries. Scholars in diplomacy traditionally refer to diplomats as "diplomats of states" or "national diplomats" with diplomats being the key referent object for any inquiry into diplomacy (Murray et al., 2011). Thus strong home country identification is often assumed among diplomats when they work on securing agreements ranging from sovereignty to trade, arms control, and security crises on behalf of the national states they represent (Wong, 2016; Jervis, 1970). It has even been argued that what diplomats "do" and what they "say" in their everyday diplomatic practices cannot be separated from their home country (Neumann, 2002; Sending et al., 2015). Still, diplomats have long been known for their skill in constructing and maintaining ambiguous identities in various social contexts, depending on the requirements of the specific negotiation goal (Murray et al., 2011). As a significant component in the work of diplomatic expatriates is to engage in negotiations with local counterparts with the aim of reaching cross-nation agreements, it is important that diplomatic expatriates are able and willing to cooperate with representatives from the host country. Therefore, developing a certain level of host country identification may help them gain the trust of their local counterparts. National identity is thus a particularly relevant issue and warrants research on this extreme type of expatriate.

In this paper, we focus specifically on the effect of home country and host country identification in remedying the adverse impact of expatriate burnout on career satisfaction. We explore career satisfaction because it has been considered of high relevance to the increasingly changing workforce and complex workplace structures - not least to mobile workers such as expatriates (Colakoglu, 2011). In this regard, it should be mentioned that career satisfaction and subjective career success are often regarded as synonyms and measured with the same scale (cf. Heslin, 2005). However, we argue that there are differences between career success and career satisfaction, especially among expatriates who have different job descriptions across countries (Dimitrova et al., 2020; Guttormsen and Francesco, 2019). While career satisfaction may not provide a sufficient indication of career success, it is a more concrete measure and associated with various organizational benefits such as lower job search intentions (Dawley et al., 2008) and higher organizational commitment (Joo and Park, 2010) that are highly relevant for organizations. We therefore focus on the concept of career satisfaction among diplomatic expatriates in this paper. Specifically, we seek to answer the question of whether a specific national identification (home or host country) has the potential to reduce the negative effects of expatriate burnout on career 
satisfaction. We do this by drawing on the Job-Demands Resources (JD-R) model (Demerouti et al., 2001; Bakker and Demerouti, 2017) as a framework for describing the effects of draining and replenishing factors for expatriates at work. By so doing we seek to answer whether a firmly grounded national identity, whether home or host country, can function as a resource that buffers the effects of burnout on career satisfaction for expatriates. By applying the JD-R model in the context of expatriation management, we make a conceptual and empirical contribution to the advancement of our knowledge on the relationship between burnout and career satisfaction and the moderating effects of national identity. This is especially important because to date very few studies have tested the JD-R model from an intercultural perspective (Rattrie and Kittler, 2014; Rattrie et al., 2020). We also contribute to expatriate home and host country identification literature by emphasizing the moderating effects of such identifications on work-related outcomes such as career satisfaction. In so doing, we provide much-needed knowledge on how working employees reshape and extend their sense of self (Arnett, 2002; Hermans and Dimaggio, 2007) in responding to exposure to diverse cultures during expatriation. Further, we relate this to the consequences of changing degrees of identifications with regard to home and host cultures (Lee $e t$ al., 2018; Lauring et al., 2018).

In the following sections, we present a review of the relevant literature as the theoretical background to this paper, followed by the hypotheses we developed and tested for this investigation.

\section{Theoretical background}

The JD-R model has often been applied as a theoretical framework for understanding employee well-being, particularly in connection to burnout (Demerouti et al., 2001; Bakker et al., 2014). The general argument is that job demands are related to health impairment and burnout, whereas job resources are related to positive work outcomes (Bakker and Demerouti, 2017; Bakker et al., 2004). According to the JD-R model, job demands are elements of work activities related to physical, emotional, or cognitive effort. Job resources, on the other hand, are aspects of work that help an individual achieve goals, alleviate job demands, or stimulate personal growth (Bakker et al., 2014; Bakker and Demerouti, 2007; Akhtar and Lee, 2010). According to the JD-R model, burnout develops when job demands are high and job resources are limited. This is because such negative 
working conditions cause energy depletion and undermine employee motivation and satisfaction (Bakker and Demerouti, 2017).

More specifically, it has been argued that burnout results from chronic stress associated with emotionally intense work demands and inadequate resources for dealing with these demands (Pines and Keinan, 2005). A central aspect of occupational burnout is the notion of lack of meaningfulness and dissatisfaction with one's life. In this way, burnout can be seen as a failure in the existential quest for meaning (Pines, 1993). One factor that generates such a feeling of failure leading to burnout has been described as self-concept uncertainty (Higgins, 1987). This term relates to confusion and lack of clarity regarding how individuals view themselves. Consequently, a clear self-concept can help individuals become better at handling emotional exhaustion and dealing with it before it becomes too intrusive in their lives (Pines and Maslach, 1978).

National identity has been described as a sense of belonging to a specific society (Igarashi, 2019), offering favorable defining characteristics of the group that can be used in positive selfcategorization (cf. Turner et al., 1987; Lauring, 2008). Hence, individuals can incorporate the positive attributes, success, and status of their group into their own self-concepts and thus achieve a clear and favorable self-image (Dutton et al. 1994; Oakes and Turner, 1980). In line with this, identification with a larger group can enhance self-worth and self-confidence (Cialdini and Richardson, 1980; Correll and Park, 2005; Johnson et al., 2006). National identity can thus be considered a form of essential emotional resource that allows fulfillment of fundamental needs such as belonging and developing a positive self-image (cf. Baumeister and Leary, 1995). This is particularly important for diplomats in foreign postings whose main duty is to represent a single country (Shaw, 2006). Hence, we argue that having a strong national identity can provide emotional sturdiness, which can assist diplomats in alleviating the consequences of burnout and thus maintain a higher level of career satisfaction (cf. Richter and Hacker, 1998; Neumann, 2012).

\section{Hypotheses}

\section{Burnout and career satisfaction}

Burnout arises as a consequence of unmet job demands, for example, when important work-related goals are blocked by external circumstances. This can lead to a feeling of failure (Pines, 1993), lack of personal accomplishment (Snyder, 1994; Densten, 2001), and low satisfaction (Andrews and Dziegielewski, 2005; Bilge, 2006; Larrabee et al., 2003). In line with this, scholars on burnout 
have argued that burnout lowers the career satisfaction of employees (Barthauer et al., 2020; Bianchi et al., 2015; Harry and Coetzee, 2013; Schaufeli and Enzmann, 1998). Hobfoll (1989), for example, found that burnout reduced employees' generic satisfaction with their careers and lowered the chances for achieving self-set criteria for developmental success. Similarly, Choi and colleagues (2012) found that high levels of burnout were related to lower job and career satisfaction among call center employees. Similarly, burnout for expatriates could be reflected in their perceived status in the organization and career satisfaction. This effect has been substantiated in a qualitative study of black expatriates living in South Korea (Dos Santos, 2020), where burnout negatively affected career decisions and led to turnover. Accordingly, we present our baseline hypothesis on diplomats as one type of expatriate.

Hypothesis 1: $\quad$ Burnout experienced by a diplomatic expatriate will be negatively associated with career satisfaction.

\section{National identification and career satisfaction}

National identification is important for many employees, not least in global workplaces where they move across national boundaries regularly in the course of their careers (Du Bois, 2007; Mao and Shen, 2015). This is because the identity of this type can be conceived as a primary basis of the need to belong and as an emotional resource (Moreland and Levine, 1989; Stangor et al., 1992). A strong feeling of national identity can be a job resource for furthering satisfaction with the job situation and career progression, especially for diplomats who have strong attachments to the national state because of their jobs.

While attachment to a specific national identity can yield feelings of confidence and belongingness, empirical studies have shown that people exhibit varying degrees of national identification (Das et al., 2008). For example, this has been demonstrated in studies of various racial groups in the USA (Devos and Banaji, 2005). Such findings are central because national identification has been found to have strong career-long positive consequences for satisfaction and organizational commitment (Das et al., 2008).

The relationship between national identity and career satisfaction is particularly salient for expatriates. This group of employees works in various locations during what is career-wise the most crucial period of their working life and may often experience uncertainties in national 
affiliation (Adams and Van de Vijver, 2015; Grinstein and Wathieu, 2012). With regard to home county identification, past research has shown that it is related to career satisfaction. For example, in their study of Latino immigrants in the US, Valdivia and Flores (2012) found that strong home country identification had a positive effect on job satisfaction. In a similar vein, empirical studies with a Latina population showed that high degrees of home country identification were associated with high levels of career self-efficacy (Gushue, 2006; Gushue and Whitson, 2006). Home country identification is also often related to one's sense of worth, which is an important positive work motivator (Shinnar, 2007). In another study, Timotijevic and Breakwell (2000) showed that migrants from former Yugoslavia to Britain maintained continuity in their home country identity. This was because their home country identification was of significance to them for retaining their sense of self-efficacy and self-esteem, which in turn were associated with career satisfaction and development. Finally, in a study of Nordic expatriates in China and Japan, Peltokorpi and Zhang (2020) found that expatriates tried to hold on to values and business practices from their home country. Moreover, those who were successful in shaping the local environment to resemble that of their home country tended to have a greater sense of career-related achievement. Diplomatic expatriates are an example of a group of expatriates where home country identification is traditionally expected to be strong. In this regard, diplomats are often criticized if they live too luxuriously abroad and become alien to their home countries; they are viewed as having lost touch with their own people (Sofer, 1997). As such, home country national identity becomes part of the personal identity of diplomats (Faizullaev, 2006). In line with this, we hypothesize the following:

Hypothesis 2a: Diplomatic expatriates with high identification with their home country will have a higher level of career satisfaction.

While we argue that strong home country identification should have positive implications for career satisfaction, strong host country identification may be beneficial as well. Migration and expatriation studies provide ample empirical evidence on the positive effect of strong host country identification. In an empirical study of expatriates working in Malaysia, Tan (2010) found that expatriates who identified more strongly with the host country were more willing to contribute to the Malaysian economy and in turn were more satisfied with their careers. Similar results were also found among Asian American workers - a strong US identity reduced occupational stress and 
strain and helped increase job satisfaction and career development (Au et al., 1998; Leong, 2001; Leong and Chou, 1994). Mace and Carr (2005) further showed that immigrant workers in New Zealand with a strong host country identity were more likely to achieve full employment and had higher levels of job satisfaction and a more satisfying career trajectory. Research on self-initiated expatriates also showed that the development of a strong host country identity resulted in positive work outcomes related to career advancement (Hajro et al., 2017).

For expatriates, a strong host country identity is associated with their need to be accepted, valued, and respected in the host country, as well as the need to belong (Ellemers et al., 2002; Smith and Tyler, 1997). The more expatriates start to define themselves by employing host country culture, the more their local colleagues accept them (Zhang et al., 2018). Hence developing a strong host country identity helps expatriates adjust and develop their career in the new context (Berry, 1997; Phinney et al., 2001). When they identify strongly with their host country, expatriates are motivated to fully utilize their skills and work on their own professional development and achieve career related self-actualization in the host country (Adler, 1977; Aycan and Berry, 1996).

While diplomatic expatriates are expected to have a strong identification with the home country, they also need simultaneously to manage multiple complex roles in the host country (Cornut, 2015). The daily work of a diplomatic expatriate is far more sophisticated than the representation of one's home country. Diplomats are often expected to speak the language and have a deep understanding of the host country (Smith, 2011). While diplomatic expatriates work on behalf of their nation states, we argue they also have personal needs to achieve self-actualization in the host country. This becomes especially explicit when the tension between the "homebound good husband" and the "hero script of the nomadic diplomat" leads to many diplomats working without accompanying families (Neumann, 2005: 84). Diplomats are essentially public sector employees on repeated international assignments with the same need to feel motivated in their work as other types of expatriates. Thus, we expect that a strong feeling of attachment to the host country during the posting could also be a job resource that improves the job situation of diplomatic expatriates and contributes to career progression. In line with this, we hypothesize the following:

Hypothesis 2b: Diplomatic expatriates with high identification with their host country will have a higher level of career satisfaction. 
As we have argued that both high home and high host country identification increase career satisfaction separately, we also argue that a combination of high home and high host country identity will have positive implications in this regard. This is due to the usefulness of having identifications with both home and host country when working abroad (Tadmor et al., 2012). Expatriates with dual identifications have been found to have greater cultural competence and are more likely to have better careers (Gillespie et al., 2010; Hong and Doz, 2013). Such expatriates have also been found to have more social capital, which could also be the case for diplomats (Fitzsimmons et al., 2017). In this regard, scholars in diplomacy have noted that diplomats are often called upon to negotiate their 'selves' and may experience identity confusion in their efforts to interpret both their home countries and the posted host countries as a "wanderer among diverse cultures" (Sofer, 1997: 182). In attempting to create a "third culture" between their home country and host countries, diplomatic expatriates juggle between acquiring a deep knowledge of the host country and refraining from developing feelings for it. Based on this, we present our fourth hypothesis:

Hypothesis 2c: Diplomatic expatriates with high identification with both their home and host country will have a higher level of career satisfaction.

\section{Interaction between burnout, career satisfaction, and national identity}

We have argued that burnout caused by high job demands has a negative effect on career satisfaction. On the other hand, we have presented national identity, in the form of home and host country identification, as an emotional resource that could increase expatriates' satisfaction with their work situation and career (cf. Richter and Hacker, 1998; Pines and Maslach, 1978; Wilk and Moynihan, 2005; Liu et al., 2020). As a third step in our argumentation, we will discuss the interaction between burnout, national identity, and career satisfaction. Here, in line with the JD-R model, we predict that the emotional resources encompassed in strong feelings of national identity may buffer the negative emotions that burnout creates in relation to one's current career situation. While only a few studies have dealt with the buffering role of national identity, there are some indications that a specific national identification could have an impact on the relationship between emotional strain on the job and positive work outcomes. For example, Das, Dharwadkar, and 
Brandes (2008) demonstrated that the relation between burnout and organizational identification in the Indian call center sector was moderated by the centrality of national identity to individuals. This could be related to the feelings of dissonance in one's identity enhancing the perceived level of stress and burnout among employees (Philips et al., 2006; Raskin, 2006). On the other hand, national identity has also been considered a personal emotional resource with a buffering effect on career satisfaction. For example, Wassermann and colleagues (2017) found that a strong host country identity moderated the relationship between immigrants' overqualification and workrelated well-being, including career satisfaction.

Accordingly, based on the above findings and the JD-R model outlined earlier, we predict that a strong national identity in the form of either home or host country identification will reduce the negative effect that burnout would normally have on career satisfaction for diplomatic expatriate personnel. This is because national identity can work as an important form of emotional resource for expatriate diplomats (cf. Richter and Hacker, 1998). A strong national identification provides them with a sense of belonging to the home and/or host country, an enhanced self-image (Oakes and Turner, 1980), as well as self-worth and self-confidence (Correll and Park, 2005). This leads us to our final set of hypotheses:

Hypothesis 3: The negative effect of diplomatic expatriates' burnout on career satisfaction will be weaker for individuals with a high identification with a) home, b) host, or c) both home and host country identifications.

\section{Methods}

\section{Data collection and sample}

To test our hypotheses, data were collected through an online survey among diplomatic expatriates. The questionnaire was in English. To make sure that the questions were clear and easy to answer, we conducted pilot tests with three men and two women. The survey was then posted on the research project website and social media for diplomats and diplomatic spouses, such as the Facebook and Twitter accounts of various platforms related to diplomats and diplomatic spouses. We also managed to reach family officers in Foreign Services, who helped us distribute our survey link to further diplomats. In total, we received responses from 208 diplomats who indicated in response to filter questions that they currently worked outside their home country. Excluding those 
with missing information on the variables used in this study left 123 respondents. As shown in Table 1, 77 percent of the respondents were female. Most (67 percent) lived with their spouse or partner and 48 percent lived with children under the age of 18 . The average age was 43.94 years (range: 24 to 66 years). On average, respondents had lived in 4.5 countries for at least one year (range: 0 to 10 countries). As shown in Table 2, the expatriates were located in 53 different countries on six continents; the largest number were located in Belgium (11 respondents), followed by the Japan and the United States of America ( 8 respondents each). Most of the respondents (43.1 percent) were located in Europe, followed by Africa and the Middle East (20.3\%) and Asia (19.5 percent).

Insert Table 1 and Table 2 about here

\section{Measures}

Unless stated otherwise, items were measured on seven-point scales, with answer categories ranging from $1=$ "strongly disagree" to $7=$ "strongly agree." Scales were formed by taking the mean of each respondent's responses.

Career satisfaction was measured with three items from Greenhaus et al. (1990). Sample items are "I am satisfied with the success I have achieved in my career" and "I am satisfied with the progress I have made toward meeting my goals in regard to income." Cronbach's alpha was 0.78 .

Burnout was measured with six items adapted from Hollet-Haudebert et al. (2011), a short version of the General Burnout Questionnaire (Schaufeli and Van Dierendonck, 2000). Sample items are "I feel exhausted from my activities" and "Being involved in all these activities is really a strain for me." Answer categories were 1 = "never", 2 = "almost never", 3 = "sometimes", $4=$ "fairly often" and 5 = "very often". Cronbach's alpha was 0.80 .

Home and host country identification were each measured using three items from Roccas et al.'s (2008) "identification with groups" scale that measured the importance of the group as part of self-definition, i.e. how much the person viewed the group as a part of who he or she is. The items were "Being ... is an important part of my identity," "It is important to me that I view myself 
as ...," and "It is important to me that others see me as ..." [2]. To measure identification with different countries (i.e. home country and host country), we used the referent "a national of my home country" to measure identification with the home country and "belonging to the current host country" to measure identification with the current host country. Cronbach's alpha was 0.89 (home country) and 0.95 (host country). For home country identification, the scale's mean was 5.88 (SD $=1.12)$ and for host country identification $3.31(\mathrm{SD}=1.58)$. Using the mean as a cutoff value ${ }^{[3]}$, we dichotomized home country identification and host country identification, respectively, and used the dichotomized variables to create dummy variables for four categories reflecting different levels of identification with home country and host country: low home country and low host country identification $(n=23)$, low home country and high host country identification $(n=21)$, high home country and low host country identification $(n=42)$ and high home country and high host country identification $(\mathrm{n}=37)$.

In addition, we collected demographic information on respondents' gender ( $0=$ 'man', $1=$ 'woman'), age (in years), whether they lived with a spouse or partner ( $1=$ yes), and whether they lived with any children under the age of 18 (1=yes).

Analyses

Confirmatory factor analysis using $\mathrm{R}$ software showed an acceptable fit of our measurement model $\left(\Delta \chi^{2}=119.59, \mathrm{df}=79, p<0.001 ; \mathrm{TLI}=0.98 ; \mathrm{CFI}=0.98 ; \mathrm{RMSEA}=0.07\right)$; this fit the data significantly better than a one-factor solution $\left(\Delta \chi^{2}=975.52\right.$, df $=90, p<0.001$; TLI=0.76; $\mathrm{CFI}=0.80 ; \mathrm{RMSEA}=0.28$ ) or an alternative three-factor solution where home and host country identification were combined into one factor $\left(\Delta \chi^{2}=604.03\right.$, df $=87, p<0.001$; TLI=0.86; $\mathrm{CFI}=0.88$; $\mathrm{RMSEA}=0.22$ ).

The hypotheses were tested using OLS regression with PROCESS version 3.5 (Hayes 2017) in SPSS version 26 (IBM 2019), with career satisfaction as a dependent variable. To facilitate interpretation of the moderating effect, the variable burnout was centered before

\footnotetext{
${ }^{2}$ A fourth item ("When I talk about ..., I usually say 'we' rather than 'they'”), had been included in the survey as well, both for home country identification and host country identification, but was removed from both scales after confirmatory factor analysis showed low standardized loadings on the respective latent variable $(0.51$ and 0.43 , respectively) (Hair et al., 2019, p. 674). Removing the items led to a significant improvement in the model's chisquare $\left(\Delta \chi^{2}=57.74, \mathrm{df}=29, p<.01\right)$.

${ }^{3}$ We explored alternative cutoff points, notably the midpoint of the scale and the median. With regard to the former, the number of cases with home country identification below or at the scale's midpoint (4) was 14, i.e., too few for meaningful analyses. When using the median as a cutoff, the results were similar to those based on the mean as a cutoff, and led to the same conclusions concerning our hypotheses.
} 
creating the interaction terms. Model 7 in Table 3 includes the control variables (gender, age, living with spouse or partner, living with children, and number of countries) together with our focal independent variable (burnout) and the dummy variables for various combinations of high vs. low home and host country identification (reference category: low home country and low host country identification). Next, we added the interaction terms between burnout and each of the three dummy variables for home country and host country identification (Models 8 to 11).

Insert Table 3 about here

\section{Results}

Our findings showed no association between career satisfaction and respondents' gender, age, family situation, and the number of countries they had lived in (Table 1). Turning to our hypotheses, Hypothesis 1 concerned the association between diplomatic expatriates' burnout and career satisfaction. As shown in Table 3, we found a significant negative association between burnout and career satisfaction (Model 2: $b=-0.56, p<0.001$ ), suggesting that expatriates who felt burnt out were less satisfied with their careers. This provided support for Hypothesis 1.

Hypothesis 2a, 2b, and 2c concerned the effect of home and host country identification on career satisfaction. We found support for the hypothesis that individuals with high-home country identification but low-host country identity had a more positive perception of their careers (Model 6: $b=0.68, p<0.05$ ). Also as expected, there was a significant positive effect of having both high home and high host country identifications (Model 6: $b=1.01, p<0.01$ ), suggesting that those individuals were more satisfied with their careers. However, there was no significant effect of having high host country identity and low home country identity. This provided support for Hypothesis $2 \mathrm{a}$ and $2 \mathrm{c}$ but not for $2 \mathrm{~b}$.

Hypothesis $3 \mathrm{a}, 3 \mathrm{~b}$, and $3 \mathrm{c}$ predicted that the negative effect of expatriate burnout on career satisfaction would be buffered when either home country or host country identification or both were high. As shown in Model 11, the interaction was significant only when both home and host country identification were high $(b=0.87, p<0.05)$. We then conducted a simple slope analysis to assess the results in more detail (Aiken and West, 1991). When diplomatic expatriates have low 
home and low-host identification, the relationship between burnout and satisfaction is negatively significant $(b=-0.82, p<0.01)$. From this, it was clear that when diplomatic expatriates have both high home and high host identification, the relationship between burnout and satisfaction is not significant $(b=-0.21, n s)$. Figure 1 presents the interaction plot. Thus, Hypothesis $3 \mathrm{c}$ was supported and Hypothesis $3 \mathrm{a}$ and $3 \mathrm{~b}$ were not supported. In summary, Hypothesis 1, 2a, 2c, and $3 \mathrm{c}$ were supported.

Insert Figure 1 about here

\section{Discussion}

Apart from the strong direct effect of burnout on career satisfaction, our study yielded other interesting results. First, we found that not all combinations of high and low home or host country identifications had similar effects on career satisfaction. It is noticeable that having a high host country identity is not sufficient if the home country identity is low. This may be because for diplomatic expatriates, host country identity does not provide as strong an emotional resource as home country identity. The strongest effect on career satisfaction was achieved when both home and host country identification were high. Similar results were found when we examined the interaction between burnout, career satisfaction, and home/host country identity. Here we also found that the negative effect of burnout was reduced only when there were strong identifications with both home and host countries.

As described briefly above, our findings contribute to the use of the JD-R model in international business and management research by emphasizing high home combined with high host country identification as a job resource that can buffer the effect of burnout on career satisfaction. Our results are in line with the JD-R model (Bakker and Demerouti, 2017) and predict that high job demands resulting in burnout will also have negative consequences with regard to job and career satisfaction in general. Thus, our findings are consistent with previous studies showing that negative work outcomes can result from burnout among both expatriates (Dos Santos, 2020) and domestic employees (Andrews and Dziegielewski, 2005; Bilge, 2006; Larrabee et al., 2003). 
The finding that a high level of home country identification had a positive direct association with career satisfaction is in line with research demonstrating the positive effects of strong identification with their home country on the part of immigrants (Valdivia and Flores, 2012; Timotijevic and Breakwell, 2000) and expatriates (Peltokorpi and Zhang, 2020). However, contrary to many previous studies (e.g., Hajro et al, 2017; Mace and Carr, 2005; Zhang et al., 2017; Ellemers et al, 2002) we did not find an effect on career satisfaction when there was high host country identification. Instead, strong home country identification had a positive effect on the career satisfaction of diplomatic expatriates. While this may sound intuitive for diplomats who are often seen as the representatives of their home countries, we find it interesting because developing a deep understanding of the host country is primarily a diplomat's job (Cornut, 2015). This confirms previous research findings that the diplomatic expatriate needs to strike a fine balance in disaggregating the state and oneself (Hoffman, 2003). While developing a strong identification with the host country yields positive work outcomes for business expatriates (e.g., Peltokorpi and Zhang, 2020), this is not the case for diplomatic expatriates, to whom the home country becomes an individual self-schema (Faizullaev, 2006).

It is interesting, however, that despite the insignificant result of the effect of strong host country identification on the career satisfaction of diplomatic expatriates, our results show that home country identification and host country identification collectively increased career satisfaction as well as moderated the relation between diplomatic expatriate burnout and career satisfaction. In other words, identifying with the home country alone does not help relieve the negative effect of expatriate burnout when it comes to career satisfaction. By identifying with more than one group, the social identity complexity of expatriates (Roccas and Brewer, 2002) increases, which in turn helps reduce the anxiety and uncertainty encountered by expatriates during assignments abroad. Therefore, despite the differences between business expatriates and the specific type of diplomatic expatriates, our counter-intuitive findings point out that dual home and host country identification is actually important for diplomats who are not supposed to develop attachment to local cultures because of the technicalities and minutiae of their day-to-day representation work for their home countries (Muldoon, 2005).

By empirically illustrating the role of the national identity in remedying the adverse effect of expatriate burnout on career satisfaction among expatriates who engage in diplomatic assignments, this study responds to the call for contextualizing expatriate research (Selmer, 2013; 
Pinto and Caldas, 2015). In this regard, Pinto, Bader and Schuster (2017) emphasize the importance of gaining insights from expatriate communities other than the dominant business community. In addition, McNulty et al.(2017) called for more research on overlooked occupational groups such as diplomats for a better understanding of the differences between business and governmental expatriation (e.g., Waibel et al., 2018). Our study, thus, contributes to the severely under-researched form of expatriation, namely diplomatic assignments, which are among the oldest types of expatriate profession (Fliege et al., 2016; Groeneveld, 2008; Davoine et al., 2013).

The findings of this paper also contribute to the identification literature in international human resource management research in general. We found that national identification becomes more important when burnout increases. Here it becomes clear that employees with different levels of home and host country identification have different levels of resilience when it comes to burnout. At the average point of burnout, those that have high levels of both home and host country identity are most satisfied, while those with low levels of both are least so. This is in line with research advocating the importance of developing dual identifications with both home and host country when expatriates work abroad (Tadmor et al., 2012). In this situation, employees with dual identifications have been found to have more cultural competence and cultural switching capability and are more likely to have more successful careers in top management positions (Gillespie et al., 2010; Hong and Doz, 2013). Expatriates with multiple national identities are also found to have more social capital and higher levels of intercultural skills than those with fewer skills of this kind (Fitzsimmons et al., 2017). What we can see from our results is that as work starts to become tough, identifying with the host country only becomes useful if identification with the home country remains strong.

In conclusion, it can be argued that some groups defined on the basis of identification deal with high burnout significantly better than others and that the differences between the groups are most pronounced when they are at the highest levels of burnout. As such, our research supports findings from recent studies on multicultural employees in international business showing that individuals' cultural identities have become increasingly complex with different implications for work outcomes (e.g., Fitzsimmons et al., 2017; Vora et al., 2019). Moving away from the monocultural assumption of expatriates (Collings et al., 2007; Takeuchi, 2010), our findings emphasize that expatriates can identify with both home and host countries and that such dual identifications may create favorable work outcomes such as reduced effects of burnout (Brannen and Lee, 2014). 


\section{Practical implications}

The findings of this study provide important insights on diplomats as an extreme case of expatriates in relation to the requirement for host country identity. Diplomats are 'permanent expatriates'; they are constantly on the move and experience repeated international relocation. Unlike most business expatriates, who return home at the end of an assignment, diplomats continue taking on new postings. Such frequent relocation often involves comprehensive procedures in a highly institutionalized setting (Brandt and Buck, 2005; Holland, 1984). Moreover, diplomatic expatriates also engage in not-for-profit assignments all around the world, including difficult locations with danger and risk and without accompanying families. This constitutes a major source of strain and stress (Wilkinson and Singh, 2010). Finally, the work intensity of diplomats is also extremely high with the constant need to deal with crises, which can lead to burnout and career dissatisfaction. For diplomats who take on assignments without accompanying families and are expected to have a high degree of home country identification, it is recommended that the human resource personnel of foreign ministries help diplomats evaluate the risk of an identity crisis and burnout caused by the constant need to represent their home country and the inability to switch off from work.

Diplomatic expatriates would also benefit from formal human resource training that is found to be helpful for business expatriates. In this regard, studies have repeatedly demonstrated that burnout prevention can improve employee well-being and performance (Huo and Boxall, 2017; Schaufeli, 2017). Such training can make employees with the intention of working abroad aware of the high risk of burnout. As opposed to short one-time training, long-term, repeated training directed toward alleviating the perceived cultural novelty and foreignness could potentially reduce burnout. It can further enhance the diplomatic expatriate's perception of career continuation within the same organization. It is also recommended that employees organize burnout workshops to help diplomatic expatriates acknowledge the importance of their work, set reasonable goals, and manage their own expectations as well as those of home and host country colleagues (Silbiger and Pines, 2014). As a preventive strategy for expatriation stress (e.g., Lei et al., 2004), cross-cultural training covering a wide range of general topics including languages, experiences in the host country and intercultural sensitivity would also be helpful to diplomats (Morris and Robie, 2001; Tung, 1981). Good cross-cultural skills would make diplomats less anxious when they are expected to be knowledgeable about the host country upon arrival at the new posting (Smith, 2011). 
In addition to the formal organizational support from the foreign ministries, we also recommend that diplomatic expatriates take a reflexive approach in relating themselves to their home and host country (Mateu, 2006; Archer, 2007). As a powerful group with access to unique social and economic resources in the host country, expatriates in general have considerable freedom to explore their cultural identities (Adams and Van de Vijver, 2015; Li et al., 2019). Although admittedly diplomats cannot separate their work from their home countries, they need to be more conscious of the tension between themselves as employees of the public sector and the stereotypical heroic script of the nomadic diplomats (Neumann, 2005). By becoming aware and reflexive about their identifications in relation to the home and host country, diplomats can proactively prevent identity crises, reduce identity-related stress, be less vulnerable to burnout, and enjoy higher career satisfaction.

\section{Limitations and directions for future research}

Several limitations should be noted. First, a potential problem of this study could be common method bias (CMB) since the data were collected by cross-sectional self-reports (Podsakoff et al., 2003). To explore the potential for CMB, Harman (1976)'s single factor test was applied (Podsakoff et al., 2003). As noted above, the model fit of the one-factor solution was significantly worse than our measurement model and the average variance extracted was low (25 percent), suggesting that $\mathrm{CMB}$ did not significantly influence our findings. Moreover, as our main interest was in the interaction between burnout and national identification, $\mathrm{CMB}$ is less likely to be of concern because significant moderation effects cannot be caused by CMB (Siemsen et al., 2010). Moreover, results concerning the varying effects of home and host country identity cannot be caused by CMB. Further, due to the cross-sectional nature of our study, the direction of causality cannot be determined with certainty and hence we refrain from speculation concerning the direction of the measured effect. Although future studies using longitudinal designs would potentially be able to establish the direction of causality with more certainty, the relationship is likely to be dual as burnout and career satisfaction can impact each other.

Using a sample of diplomats could lead to certain limitations in terms of generalizability. Compared with diplomats, business expatriates working for multinational corporations may be perceived less as representatives of their home countries as their main working context is businessdriven. Hence, the results of our study need to be generalized with caution outside the diplomatic 
context. That said, past studies have repeatedly highlighted the importance of national identities as an explanatory variable in career development for all types of expatriates, migrants, and immigrants including non-traditional types of expatriates such as diplomats (See Miller and Kerlow-Myers 2009 for a review). We thus believe that our study provides important insights on national identity, career, and burnout issues despite the limitations of our sample. Still, we find that future studies contrasting the findings among diplomats with other types of expatriates are needed in order to assess the uniqueness of the diplomat group.

Another issue worth further consideration is the role of diplomatic spouses. The benefits of spousal support in expatriate careers have already been well established (Lauring and Selmer, 2010; Stoermer et al., forthcoming). In this regard, Davoine et al. (2013) described how spouses of diplomatic and consular expatriates, depending on their gender, took on different supporting roles. Based on a survey with European diplomatic spouses, Gudmundsdottir et al. (2019) further emphasized the important role of diplomatic spouses in the improvement of expatriate programs and policies for Foreign Ministries. In line with this research effort, we believe that more research on diplomatic spouses could be a useful way of contextualizing the understanding of diplomats in expatriate research. A particular avenue to explore the role of diplomatic spouses further would be to compare spouses that are of the same nationality as the diplomat with those who are of a different nationality. This could, for example, be diplomatic spouses with a host country nationality that may provide specific insight into the local context but may also introduce a split loyalty situation in the relationship. This issue would be particularly relevant to study in varying contexts such as developed vs. developing countries and in host countries having a crisis situation (McNulty et al., 2019). In this regard, Fliege et al. (2016) found that the health of diplomats was affected by the exposure to international relocation mobility and various personal risks and protective factors. Here a diplomatic spouse with host country nationality could be perceived as a potential protective factor or as a resource to counter the health problems and burnout that diplomats may experience.

Moreover, future studies using larger samples would be desirable in order to provide a clearer understanding of the types of benefits provided by national identification and potential differences in resources provided by home and host country identification, respectively. In addition, while our findings suggested that the effects of national identification differed at low and high 
levels of burnout, more research will be needed to provide a more detailed understanding of when and how the resources provided by home and host country identification matter.

Finally, quantitative research has limitations in relation to assessing the processual dynamics of the interplay between factors in expatriate work life. Accordingly, a qualitative and more dynamic research design could be applied to provide insight into the details and contextuality of how national identity influences the effect of burnout on career satisfaction. The results of the current study could be applied as a point of departure for developing a process model of the interaction between identity and experienced hardship in expatriate assignments.

\section{Conclusion}

This paper contributes to contextualized expatriate research on burnout and dual identifications by extending the JD-R model to international human resource management research. By identifying both home and host country identification as an important job resource for expatriates engaging in diplomatic assignments, our findings suggest that national cultural identification moderates the relationship between burnout and career satisfaction. Viewing national identification as a resource in the context of the inner well-being of diplomatic expatriates may shed more light on the mechanism involved in alleviating adjustment stress and expatriation failure. Our study thus contributes to the large body of expatriation literature and opens a new avenue of research on the role of national identification among employees in the international work setting. 


\section{References}

Adams, B. G. and van de Vijver, F. J. R. (2015), “The many faces of expatriate identity”, International Journal of Intercultural Relations, Vol. 49, pp. 322-331.

https://doi.org/10.1016/j.ijintrel.2015.05.009

Adler, S. (1977), "Maslow's need hierarchy and the adjustment of immigrants", International Migration Review, Vol.11 No. 4, pp. 444-451. https://doi.org/10.1177/019791839701100402

Aiken, L. S., West, S. G. and Reno, R. R. (1991), Multiple Regression: Testing and Interpreting Interactions, Sage.

Akhtar, S. and Lee, J. S. (2010), “Job burnout: Toward an integration of two dominant resourcebased models", Psychological Reports, Vol. 107 No. 1, pp. 193-208.

Andrews, D. R. and Dziegielewski, S. F. (2005), “The nurse manager: job satisfaction, the nursing shortage and retention”, Journal of Nursing Management, Vol.13 No. 4, pp. 286-295. https://doi.org/10.1111/j.1365-2934.2005.00567.x

Archer, M. S. (2007), Making our Way through the World: Human Reflexivity and Social Mobility, Cambridge: Cambridge University Press. https://doi.org/10.1017/CBO9780511618932

Arnett, J. J. (2002), “The psychology of globalization”, American Psychologist, Vol. 57 No. 10, pp. 774-783. https://doi.org/10.1037/0003-066X.57.10.774

Au, A. Y. W., Garey, J. G., Bermas, N. and Chan, M. M. (1998), “The relationship between acculturation and job satisfaction among Chinese immigrants in the New York city restaurant business", International Journal of Hospitality Management, Vol. 17 No. 1, pp.11-21. https://doi.org/10.1016/S0278-4319(97)00040-6 
Aycan, Z. and Berry, J. W. (1996), “Impact of employment-related experiences on immigrants' psychological well-being and adaptation to Canada", Canadian Journal of Behavioural Science/Revue Canadienne des Sciences du Comportement, Vol. 28 No. 3, pp.240. https://doi.org/10.1037/0008-400X.28.3.240

Bakker, A. B. and Demerouti, E. (2017), "Job demands-resources theory: taking stock and looking forward", Journal of Occupational Health Psychology, Vol. 22, pp. 273285. https://doi.org/10.1037/ocp0000056

Bakker, A. B., Demerouti, E. and Sanz-Vergel, A. I. (2014), "Burnout and work engagement: The JD-R approach”, Annual Reviews, Vol.1, pp. 389-411. https://doi.org/10.1146/annurevorgpsych-031413-091235

Bakker, A. B., Demerouti, E. and Verbeke, W. (2004), "Using the job demands-resources model to predict burnout and performance”, Human Resource Management, Vol. 43 No. 1, pp. 83-104. https://doi.org/10.1002/hrm.20004

Bakker, A. B., Schaufeli, W. B., Sixma, H. J., Bosveld, W. and Van Dierendonck, D. (2000), "Patient demands, lack of reciprocity, and burnout: A five-year longitudinal study among general practitioners", Journal of Organizational Behavior, Vol. 21 No. 4, pp.425-441.

Barthauer, L., Kaucher, P., Spurk, D. and Kauffeld, S. (2020), “Burnout and career (un) sustainability: Looking into the Blackbox of burnout triggered career turnover intentions", Journal of Vocational Behavior, Vol. 117, pp. 103334. https://doi.org/10.1016/j.jvb.2019.103334

Baumeister, R. F. and Leary, M. R. (1995), “The need to belong: Desire for interpersonal attachments as a fundamental human motivation", Psychological Bulletin, Vol. 117, pp. 497-529. https://doi.org/10.1037/0033-2909.117.3.497 
Berry, J. W. (1997), "Immigration, acculturation, and adaptation", Applied Psychology: An International Review, Vol. 46 No. 1, 5-34. https://doi.org/10.1111/j.1464-0597.1997.tb01087.x

Bhanugopan, R. and Fish, A. (2006), "An empirical investigation of job burnout among expatriates", Personnel Review, Vol. 35 No. 4, pp. 449-468.

https://doi.org/10.1108/00483480610670607

Bianchi, R., Schonfeld, I. S. and Laurent, E. (2015), "Burnout-depression overlap: A review”, Clinical Psychology Review, Vol. 36, pp. 28-41. https://doi.org/10.1016/j.cpr.2015.01.004

Bilge, F. (2006), "Examining the burnout of academics in relation to job satisfaction and other factors", Social Behavior and Personality: An International Journal, Vol. 34 No. 9, pp. 11511160. https://doi.org/10.2224/sbp.2006.34.9.1151

Brandt, E. and Buck, C. F. (2005), Auswärtiges Amt: Diplomatie als Beruf, Springer-Verlag. https://doi.org/10.1007/978-3-531-90050-6

Brannen, M. Y. and Lee, F. (2014), "Bridging cultural divides: Traversing organizational and psychological perspectives on multiculturalism", In Benet-Martinez V. and Hong, Y-Y. (Ed.s), The Oxford Handbook of Multicultural Identity, London: Oxford University Press, pp. 417-437. https://doi.org/10.1093/oxfordhb/9780199796694.013.021

Choi, S., Cheong, K. J. and Feinberg, R. A. (2012), "Moderating effects of supervisor support, monetary rewards, and career paths on the relationship between job burnout and turnover intentions in the context of call centers", Managing Service Quality, Vol. 22 No. 5, pp. 492-516. https://doi.org/10.1108/09604521211281396

Cialdini, R. B. and Richardson, K. D. (1980), "Two indirect tactics of image management: Basking and blasting", Journal of Personality and Social Psychology, Vol. 39, pp. 406-415. https://doi.org/10.1037/0022-3514.39.3.406 
Colakoglu, S. N. (2011), "The impact of career boundarylessness on subjective career success: The role of career competencies, career autonomy, and career insecurity", Journal of Vocational Behavior, Vol. 79 No. 1, pp. 47-59. https://doi.org/10.1016/j.jvb.2010.09.011

Collings, D. G., Scullion, H. and Morley, M. J. (2007), “Changing patterns of global staffing in the multinational enterprise: Challenges to the conventional expatriate assignment and emerging alternatives", Journal of World Business, Vol. 42 No. 2, pp. 198-213. https://doi.org/10.1016/j.jwb.2007.02.005

Cornut, J. (2015), "To be a diplomat abroad: Diplomatic practice at embassies", Cooperation and Conflict, Vol. 50 No.3, pp. 385-401. https://doi.org/10.1177/0010836715574912

Correll, J. and Park, B. (2005), "A model of the ingroup as a resource", Personality and Social Psychology Review, Vol. 9, pp. 341-359. https://doi.org/10.1207/s15327957pspr0904_4

Das, D., Dharwadkar, R. and Brandes, P. (2008), "The importance of beingIndian: Identity centrality and work outcomes in an off-shored call center in India", Human Relations, Vol. 61 No. 11, pp. 1499-1530. https://doi.org/10.1177/0018726708096636

Davoine, E., Ravasi, C., Salamin, X. and Cudré-Mauroux, C. (2013), “A “dramaturgical” analysis of spouse role enactment in expatriation : An exploratory gender comparative study in the diplomatic and consular field", Journal of Global Mobility, Vol. 1 No. 1, pp. 92-112. https://doi.org/10.1108/JGM-09-2012-0005

Dawley, D.D., Andrews, M.C. and Bucklew, N.S. (2008), "Mentoring, supervisor support, and perceived organizational support: what matters most?", Leadership \& Organization Development Journal, Vol. 29 No. 3, pp. 235-247. https://doi.org/10.1108/01437730810861290

Demerouti, E., Bakker, A. B., Nachreiner, F. and Schaufeli, W. B. (2001), "The job demandsresources model of burnout", Journal of Applied Psychology, Vol. 86 No. 3, pp. 499. https://doi.org/10.1037/0021-9010.86.3.499 
Densten, I. L. (2001), "Re-thinking burnout”, Journal of Organizational Behavior, Vol. 22 No. 8, pp. 833-847. https://doi.org/10.1002/job.115

Devos, T. and Banaji, M.R. (2005), “American = white?”, Journal of Personality and Social Psychology, Vol. 88 No. 3, pp. 447-66. https://doi.org/10.1037/0022-3514.88.3.447

Dimitrova, M., Chia, S. I., Shaffer, M. A. and Tay-Lee, C. (2020), "Forgotten travelers: Adjustment and career implications of international business travel for expatriates", Journal of International Management, Vol. 26 No. 1, pp. 100707.

https://doi.org/10.1016/j.intman.2019.100707

Dos Santos, L.M. (2020), “Stress, burnout, and turnover issues of Black expatriate education professionals in South Korea: Social biases, discrimination, and workplace bullying", International Journal of Environment Research and Public Health, Vol. 17, pp. 3851. https://doi.org/10.3390/ijerph17113851

Du Bois, I. (2007), "Hiding and struggling with national identity: American expatriates in Germany", Jungbluth and Meierkord (Ed.s), Identities in Migration Contexts, Tübingen: Narr, pp. 11-35.

Dutton, J. E., Dukerich, J. M. and Harquail, C. V. (1994), “Organizational images and member identification", Administrative Science Quarterly, Vol. 39 No. 2, pp. 239-263. https://doi.org/10.2307/2393235

Dyląg, A., Jaworek, M., Karwowski, W., Kożusznik, M. and Marek, T. (2013), “Discrepancy between individual and organizational values: Occupational burnout and work engagement among white-collar workers”, International Journal of Industrial Ergonomics, Vol. 43 No. 3, pp. 225-231. https://doi.org/10.1016/j.ergon.2013.01.002 
Ellemers, N., Spears, R. and Doosje, B. (2002), "Self and social identity", Annual Review of Psychology, Vol. 53 No. 1, pp. 161-186.

https://doi.org/10.1146/annurev.psych.53.100901.135228

Faizullaev, A. (2006), "Diplomacy and self", Diplomacy and Statecraft, Vol. 17 No. 3, pp. 497522. https://doi.org/10.1080/09592290600867578

Fitzsimmons, S. R., Liao, Y. and Thomas, D. C. (2017), "From crossing cultures to straddling them: An empirical examination of outcomes for multicultural employees", Journal of International Business Studies, Vol. 48 No. 1, pp. 63-89. https://doi.org/10.1057/s41267-0160053-9

Fleischmann, F. and Phalet, K. (2018), "Religion and national identification in Europe: Comparing Muslim youth in Belgium, England, Germany, the Netherlands, and Sweden", Journal of Cross-Cultural Psychology, Vol. 49 No. 1, pp. $44-61$. https://doi.org/10.1177/0022022117741988

Fliege, H., Waibel, S., Rüger, H., Hillmann, J., Ruppenthal, S., Schneider, N. F. and Bellinger, M. M. (2016), "Diplomats' quality of life: The role of risk factors and coping resources", International Journal of Intercultural Relations, Vol. 51, pp. 14-28. https://doi.org/10.1016/j.ijintrel.2016.01.001

Gillespie, K., McBride, J. B. and Riddle, L. (2010), "Globalization, Biculturalism and Cosmopolitanism The Acculturation Status of Mexicans in Upper Management", International Journal of Cross Cultural Management, Vol. 10 No. 1, pp. 37-53.

Gould-Davies, N. (2013), "The intimate dance of diplomacy: In praise of practice", International Affairs, Vol. 89 No. 6, pp. 1459-1467. https://doi.org/10.1111/1468-2346.12084 
Greenhaus, J. H., Parasuraman, S. and Wormley, W. M. (1990), "Effects of race on organizational experiences, job performance evaluations, and career outcomes", Academy of Management Journal, Vol. 33 No. 1, pp. 64-86. https://doi.org/10.5465/256352

Grinstein, A. and Wathieu, L. (2012), "Happily (mal)adjusted: Cosmopolitan identity and expatriate adjustment", International Journal of Research in Marketing, Vol. 29, pp. 337-345. https://doi.org/10.1016/j.ijresmar.2012.03.003

Groeneveld, S. (2008), "Dual careers and diplomacy: the willingness of dual-career couples to accept an international assignment within the Dutch foreign services", Review of Public Personnel Administration, Vol. 28 No. 1, pp. 20-43. https://doi.org/10.1177/0734371X07309540

Gudmundsdottir, S., Gudlaugsson, T.O. and Adalsteinsson, G.D. (2019), “The diplomatic spouse: Relationships between adjustment, social support and satisfaction with life", Journal of Global Mobility, Vol. 7 No. 1, pp. 103-122. https://doi.org/10.1108/JGM-09-2018-0043

Gushue, G. V. (2006), "The relationship of ethnic identity, career decision-making self-efficacy and outcome expectations among Latino/a high school students", Journal of Vocational Behavior, Vol. 68 No. 1, pp. 85-95. https://doi.org/10.1016/j.jvb.2005.03.002

Gushue, George V. and Melissa L. Whitson. (2006), “The relationship among support, ethnic identity, career decision self-efficacy, and outcome expectations in African American high school students: Applying social cognitive career theory", Journal of Career Development, Vol. 33 No. 2, pp. 112-124. https://doi.org/10.1177/0894845306293416

Guttormsen, D.S.A. and Francesco, A.M. (2019), "Status and success: Do lower status expatriates in multinational corporations experience different types of success? ", Journal of Global Mobility, Vol. 7 No.4, pp. 364-380. https://doi.org/10.1108/JGM-02-2019-0016

Hair, J. H., Black, W. C., Babin, B. J. and Anderson, R. E. (2019), Multivariate Data Analysis (Eigth edition), Andover: Cengage 
Hajro, A., Zilinskaite, M. and Stahl, G. (2017), “Acculturation of highly-qualified migrants at the workplace: The importance of individual coping strategies and organizational climate for inclusion", Academy of Management Annual Meeting Proceedings, Vol. 2017, No. 1, pp.13666. https://doi.org/10.5465/ambpp.2017.13666abstract

Harman, H. H., (1976), Modern factor analysis, Chicago: University of Chicago Press.

Harry, N. and Coetzee, M. (2013), "Sense of coherence, career adaptability and burnout of earlycareer Black staff in the call centre environment”, SA Journal of Industrial Psychology, Vol. 39 No. 2, pp. 1-10. https://doi.org/10.4102/sajip.v39i2.1138

Hayes, A. F. (2017), Introduction to mediation, moderation, and conditional process analysis: A regression-based approach, Guilford publications.

Hermans, H. J. and Dimaggio, G. (2007), "Self, identity, and globalization in times of uncertainty: A dialogical analysis”, Review of General Psychology, Vol. 11 No. 1, pp. 31-61. https://doi.org/10.1037/1089-2680.11.1.31

Heslin, P. A. (2005), “Conceptualizing and evaluating career success”, Journal of Organizational Behavior, Vol. 26 No. 2, pp. 113-136.

Higgins, E. T. (1987), "Self-discrepancy: A theory relating self and affect”, Psychological Review, Vol. 3, pp. 319-340. https://doi.org/10.1037/0033-295X.94.3.319

Hobfoll, S. E. (1989), “Conservation of resources: A new attempt at conceptualizing stress", American Psychologist, Vol. 44 No. 3, pp. 513. https://doi.org/10.1037/0003066X.44.3.513

Hoffman, J. (2003), "Reconstructing diplomacy”, The British Journal of Politics and International Relations, Vol. 5 No. 4, 525-542. https://doi.org/10.1111/1467-856X.00118 
Holland, H. M. (1984), Managing diplomacy: the United States and Japan, Hoover Press, Stanford.

Hollet-Haudebert, S., Mulki, J. P. and Fournier, C. (2011), "Neglected burnout dimensions: Effect of depersonalization and personal nonaccomplishment on organizational commitment of salespeople", Journal of Personal Selling and Sales Management, Vol. 31 No. 4, pp. 411-428. https://doi.org/10.2753/PSS0885-3134310404

Hong, H.J. and Doz, Y. (2013), "L'Oreal Masters Multiculturalism”, Harvard Business Review, Vol. 91 No. 6, pp. 114-118.

Horak, S., Farndale, E., Brannen, M. Y. and Collings, D. G. (2019), "International human resource management in an era of political nationalism”, Thunderbird International Business Review, Vol. 61 No. 3, pp. 471-480. https://doi.org/10.1002/tie.21959

Huo, M. L. and Boxall, P. (2017), "Lean production and the well-being of the frontline manager: The job demands-resources model as a diagnostic tool in Chinese manufacturing", Asia Pacific Journal of Human Resources, Vol. 55 No. 3, pp. 280-297. https://doi.org/10.1111/17447941.12152

Igarashi, A. (2019), "Till multiculturalism do us apart: multicultural policies and the national identification of immigrants in European countries”, Social Science Research, Vol. 77 No. 1, pp. 88-100. https://doi.org/10.1016/j.ssresearch.2018.10.005

Jervis R (1970), The Logic of Images in International Relations, New York, NY: Columbia University Press.

Johnson, A. L., Crawford, M. T., Sherman, S. J., Rutchick, A. M., Hamilton, D. L., Ferreira, M. B., et al. (2006), “A functional perspective on group memberships: Differential need fulfilment 
in a group typology", Journal of Experimental Psychology, Vol. 42, pp. 707-719.

https://doi.org/10.1016/j.jesp.2005.08.002

Joo, B.(B). and Park, S. (2010), "Career satisfaction, organizational commitment, and turnover intention: The effects of goal orientation, organizational learning culture and developmental feedback", Leadership \& Organization Development Journal, Vol. 31 No. 6, pp. 482-500. https://doi.org/10.1108/01437731011069999

Larrabee, J. H., Janney, M. A., Ostrow, C. L., Withrow, M. L., Hobbs, G. R. and Burant, C. (2003), "Predicting registered nurse job satisfaction and intent to leave", JONA: The Journal of Nursing Administration, Vol. 33 No. 5, pp. 271-283. https://doi.org/10.1097/00005110200305000-00003

Lauring, J. (2008), "Rethinking social identity theory in international encounters: Language use as a negotiated object for identity making", International Journal of Cross Cultural Management, Vol. 8, No (3), pp. 343-361. https://doi.org/10.1177/1470595808096673

Lauring, J., Bjerregaard, T. and Klitmøller, A. (2018), "Understanding culture in international management: Functionalism, constructivism, and the emerging practice turn", International Studies of Management and Organization, Vol. 48, No (3), pp. 264-276. https://doi.org/10.1080/00208825.2018.1480869

Lauring, J. and Selmer, J. (2010), "The supportive expatriate spouse: An ethnographic study of spouse involvement in expatriate careers", International Business Review, Vol. 19, No (1), pp. 59-69. https://doi.org/10.1016/j.ibusrev.2009.09.006

Lee, Y. T., Masuda, A. D., Fu, X. and Reiche, B. S. (2018), "Navigating between home, host, and global: Consequences of multicultural team members' identity configurations", Academy of Management Discoveries, Vol. 4 No. 2, pp. 180-201. https://doi.org/10.5465/amd.2016.0063 
Lei, L., Liang, Y.X. and Krieger, G.R. (2004), "Stress in Expatriates", Clinics in Occupational and Environmental Medicine, Vol. 4 No. 1, pp. 221- 229.

https://doi.org/10.1016/j.coem.2003.12.001

Leonardelli, G. and Toh, S. M. (2011), "Perceiving expatriate coworkers as foreigners encourages aid: Social categorization and procedural justice together improve intergroup cooperation and dual identity", Psychological Science, Vol. 22 No. 1, pp. 110-117. https://doi.org/10.1177/0956797610391913

Leong, F. T. and Chou, E. L. (1994), “The role of ethnic identity and acculturation in the vocational behavior of Asian Americans: An integrative review", Journal of Vocational Behavior, Vol. 44 No. 2, pp. 155-172. https://doi.org/10.1006/jvbe.1994.1011

Leong, F. T. (2001), "The role of acculturation in the career adjustment of Asian American workers: A test of Leong and Chou's (1994) formulations", Cultural Diversity and Ethnic Minority Psychology, Vol. 7 No. 3, pp. 262. https://doi.org/10.1037/1099-9809.7.3.262

Li, C., Zhang, L. E. and Harzing, A. W. (2019), "Of ostriches, frogs, birds and lizards: A dynamic framework of cultural identity negotiation strategies in an era of global mobility”, Journal of Global Mobility, Vol. 7 No. 3, pp. 239-254. https://doi.org/10.1108/JGM04-2019-0021

Liu, H., Zou, H. Y., Wang, H. J., Xu, X. and Liao, J. Q. (2020), “Do emotional labour strategies influence emotional exhaustion and professional identity or vice versa? Evidence from new nurses", Journal of Advanced Nursing, Vol. 76 No. 2, pp. 577-587. https://doi.org/10.1111/jan.14266

Mace, K. A. and Carr, S. C. (2005), "Immigrant job hunting, labour market experiences, and feelings about occupational satisfaction in New Zealand: An exploratory study", New Zealand Journal of Psychology, Vol. 34, pp. 97-109 
Mao, J. and Shen, Y. (2015), "Cultural identity change in expatriates: A social network perspective", Human Relations, Vol. 68 No. 10, pp. 1533-1556.

https://doi.org/10.1177/0018726714561699

Mateu, M. (2006), "Reflexivity as a Facilitator to Adjusting to a New Culture", International Journal of Learning, Vol. 12 No. 12, pp.55-62. https://doi.org/10.18848/14479494/CGP/v12i12/45026

McNulty, Y., Vance, C.M. and Fisher, K. (2017), "Beyond corporate expatriation - global mobility in the sports, religious, education and non-profit sectors", Journal of Global Mobility, Vol. 5 No. 2, pp. 110-122. https://doi.org/10.1108/JGM-04-2017-0014

McNulty, Y., Lauring, J., Jonasson, C. and Selmer, J. (2019), "Highway to Hell? Managing expatriates in crisis", Journal of Global Mobility, Vol. 7 No. 2, pp. 157-180.

https://doi.org/10.1108/JGM-10-2018-0054

Miller, M. J. and Kerlow-Myers, A. E. (2009), "A content analysis of acculturation research in the career development literature", Journal of Career Development, Vol. 35 No. 4, pp. 352-384.

Moreland, R.L. and Levine, J.M. (1989), "Newcomers and oldtimers in small groups", In Psychology of group influence, 2nd edn. Mahwah, NJ: Lawrence Erlbaum Associates, pp. 14286.

Morris, M. A. and Robie, C. (2001), "A meta-analysis of the effects of cross-cultural training on expatriate performance and adjustment", International Journal of Training and Development, Vol. 5 No. 2, pp. 112-125. https://doi.org/10.1111/1468-2419.00126

Muldoon JP (2005), Introduction. In: Muldoon JP, Fagot Aviel J, Reitano R, et al. (Ed.s) Multilateral Diplomacy and the United Nations Today, Cambridge, MA: Westview Press, pp.314. 
Murray, S., Sharp, P., Wiseman, G., Criekemans, D. and Melissen, J. (2011), “The present and future of diplomacy and diplomatic studies”, International Studies Review, Vol. 13 No. 4, pp. 709-728. https://doi.org/10.1111/j.1468-2486.2011.01079.x

Neumann I.B. (2002), "Returning practice to the linguistic turn: The case of diplomacy", Millennium: Journal of International Studies, Vol. 31 No. 3, pp. 627-651. https://doi.org/10.1177/03058298020310031201

Neumann, I. B. (2005), 'To be a diplomat', International Studies Perspectives, Vol. 6 No. 1, pp. 72-93.

Neumann, I. B. (2012), At Home with the Diplomats. Cornell University Press.

Oakes, P. J. and Turner, J. C. (1980), "Social categorization and intergroup behaviour: Does minimal intergroup discrimination make social identity more positive? ", European Journal of Social Psychology, Vol. 10, pp. 295-301. https://doi.org/10.1002/ejsp.2420100307

Peltokorpi, V. and Zhang, L.E. (2020), "Exploring expatriate adjustment through identity perspective", International Business Review, Vol. 29 No. 3, pp. 1-14. https://doi.org/10.1016/j.ibusrev.2020.101667

Phillips, B., Tsu Wee Tan, T. and Julian, C. (2006), "The theoretical underpinnings of emotional dissonance: a framework and analysis of propositions", Journal of Services Marketing, Vol. 20 No. 7, pp. 471-478. https://doi.org/10.1108/08876040610704900

Phinney, J. S., Horenczyk, G., Liebkind, K. and Vedder, P. (2001), "Ethnic identity, immigration, and well-being: An interactional perspective", Journal of Social Issues, Vol. 57 No. 3, pp. 493-510. https://doi.org/10.1111/0022-4537.00225 
Pines, A. (1993), “Burnout: An existential perspective”, Schaufeli W.B., Maslach C., Marek T. (Ed.s), Professional Burnout: Recent Development in Theory and Research, Washington, DC: Taylor \& Francis.

Pines, A. M. and Keinan, G. (2005), "Stress and burnout: The significant difference", Personality and Individual Differences, Vol. 39 No. 3, pp. 625-635. https://doi.org/10.1016/j.paid.2005.02.009

Pines, A. and Maslach, C. (1978), "Characteristics of staff burnout in mental health settings", Psychiatric Services, Vol. 29 No. 4, pp. 233-237. https://doi.org/10.1176/ps.29.4.233

Pinto, L.H.F., Bader, B. and Schuster, T. (2017), "Dangerous settings and risky international assignments", Journal of Global Mobility, Vol. 5 No. 4, pp. 342-347. https://doi.org/10.1108/JGM-10-2017-0042

Pinto, L.H. and Caldas, R. (2015), "Making sense of expatriation”, Management Research: The Journal of the Iberoamerican Academy of Management, Vol. 13 No. 3, pp. 267-284. https://doi.org/10.1108/MRJIAM-07-2014-0559

Podsakoff, P. M., MacKenzie, S. B., Lee, J. Y. and Podsakoff, N. P. (2003), “Common method biases in behavioral research: a critical review of the literature and recommended remedies", Journal of Applied Psychology, Vol. 88 No. 5, pp. 879. https://doi.org/10.1037/00219010.88.5.879

Rahim, A. and Cosby, D.M. (2016), “A model of workplace incivility, job burnout, turnover intentions, and job performance", Journal of Management Development, Vol. 35 No. 10, pp. 1255-1265. https://doi.org/10.1108/JMD-09-2015-0138

Raskin, P. M. (2006), "Women, work, and family: Three studies of roles and identity among working mothers", The American Behavioral Scientist, Vol. 49 No. 10, pp. 1354-82. https://doi.org/10.1177/0002764206286560 
Rattrie, L. T. and Kittler, M. G. (2014), “The job demands-resources model and the international work context - a systematic review”, Journal of Global Mobility, Vol. 2 No. 3, pp. 260-279. https://doi.org/10.1108/JGM-06-2014-0018

Rattrie, L. T., Kittler, M. G. and Paul, K. I. (2020), “Culture, burnout, and engagement: A MetaAnalysis on National Cultural Values as Moderators in JD-R Theory", Applied Psychology: An International Review, Vol. 69 No. 1, pp. 176-220. https://doi.org/10.1111/apps.12209

Reade, C. (2001), "Dual identification in multinational corporations: Local managers and their psychological attachment to the subsidiary versus the global organization", International Journal of Human Resource Management, Vol. 12 No. 3, pp. 405-424.

https://doi.org/10.1080/713769627

Richter, P. and Hacker, W. (1998), Belastung und Beanspruchung: Stress, Ermüdung und Burnout im Arbeitsleben. [Workload and strain: Stress, fatigue, and burnout in working life], Heidelberg, Germany: Asanger.

Roccas, S. and Brewer, M. B. (2002), "Social identity complexity”, Personality and Social Psychology Review, Vol. 6 No. 2, pp. 88-106. https://doi.org/10.1207/S15327957PSPR0602_01

Roccas, S., Sagiv, L., Schwartz, S., Halevy, N. and Eidelson, R. (2008), “Toward a unifying model of identification with groups: Integrating theoretical perspectives", Personality and Social Psychology Review, Vol.12 No. 3, pp. 280-306. https://doi.org/10.1177/1088868308319225

Schaufeli, W. B. (2017), “Applying the job demands-resources model”, Organizational Dynamics, Vol. 2 No. 46, pp. 120-132. https://doi.org/10.1016/j.orgdyn.2017.04.008

Schaufeli, W. and Enzmann, D. (1998), The burnout companion to study and practice: A critical analysis, AD, Donker-Rotterdam. 
Schaufeli, W. B., Maslach, C. and Marek, T. (1993), Professional Burnout: Recent

Developments in Theory and Research, Washington, DC: Taylor and Francis.

Schaufeli, W.B., Van Dierendonck, D. (2000). UBOS: Utrechtse Burnout Schaal. Handleiding [UBOS Test Manual]. Lisse, The Netherlands: Swets Test Services

Sending, O. J., Pouliot, V. and Neumann, I. B (2015), Diplomacy: The Making of World Politics, Cambridge: Cambridge University Press.

Selmer, J. and Fenner, Jr, C. R. (2009), "Job factors and work outcomes of public sector expatriates", Human Resource Management Journal, Vol. 19 No. 1, pp. 75-90. https://doi.org/10.1111/j.1748-8583.2008.00084.x

Selmer, J. (2013), “JGM inaugural issue”, Journal of Global Mobility, Vol. 1 No. 1. https://doi.org/10.1108/jgm.2013.61801 aaa.001

Shaffer, M. A., Kraimer, M. L., Chen, Y. P. and Bolino, M. C. (2012), "Choices, challenges, and career consequences of global work experiences: A review and future agenda", Journal of Management, Vol. 38 No. 4, pp. 1282-1327. https://doi.org/10.1177/0149206312441834

Shaw, J. (2006), The Ambassador: Inside the Life of a Working Diplomat, Capital Books.

Shinnar, R. S. (2007), “A qualitative examination of Mexican immigrants' career development: Perceived barriers and motivators", Journal of Career Development, Vol. 33 No. 4, pp. 338-375. https://doi.org/10.1177/0894845307300413

Siemsen, E., Roth, A. and Oliveira, P. (2010), "Common method bias in regression models with linear, quadratic, and interaction effects", Organizational Research Methods, Vol. 13 No. 3, pp. 456-476. https://doi.org/10.1177/1094428109351241 
Silbiger, A., Berger, R., Barnes, B. R. and Renwick, D. W. S (2017), “Improving expatriation success: The roles of regulatory focus and burnout", British Journal of Management, Vol. 28 No. 2, pp. 231-247. https://doi.org/10.1111/1467-8551.12187

Silbiger, A. and Pines, A. M. (2014), "Expatriate stress and burnout", The International Journal of Human Resource Management, Vol. 25 No. 8, pp. 1170-1183.

https://doi.org/10.1080/09585192.2013.824911

Smith, R.F. (2011), The Craft of Political Analysis for Diplomats, Dulles, VA: Potomac Books.

Smith, H. J. and Tyler, T. R. (1997), "Choosing the right pond: The impact of group membership on self-esteem and group-oriented behavior", Journal of Experimental Social Psychology, Vol. 33 No. 2, pp. 146-170. https://doi.org/10.1006/jesp.1996.1318

Snyder, C. R. (1994), The psychology of hope: You can get there from here, The Free Press: New York.

Sofer, S. (1997), “The diplomat as a stranger”, Diplomacy and Statecraft, Vol. 8 No. 3, pp. 179186, https://doi.org/10.1080/09592299708406061

Stangor, C., Lynch, L., Duan, C. and Glas, B. (1992), "Categorization of individuals on the basis of multiple social features", Journal of Personality and Social Psychology, Vol. 62, pp. 207-18. https://doi.org/10.1037/0022-3514.62.2.207

Stoermer, S., Selmer, J. and Lauring, J. (forthcoming), “Expatriate partners' personality and its influence on acculturation into a new cultural context: Examining the role of dispositional affectivity", International Journal of Cross Cultural Management. https://doi.org/10.1177/14705958211057364

Tadmor, C. T., Galinsky, A. D. and Maddux, W. W. (2012), "Getting the most out of living abroad: biculturalism and integrative complexity as key drivers of creative and professional 
success", Journal of Personality and Social Psychology, Vol. 103 No. 3, pp. 520-542. https://doi.org/10.1037/a0029360

Takeuchi, R. (2010), “A critical review of expatriate adjustment research through a multiple stakeholder view: Progress, emerging trends, and prospects", Journal of Management, Vol. 36 No. 4, pp. 1040-1064. https://doi.org/10.1177/0149206309349308

Tan, C-H. (2010), "Career satisfaction and willingness to contribute to Malaysian economy: Skilled migrants in Malaysia", Journal of Identity and Migration Studies, Vol. 4 No. 1, pp. 35.

Timotijevic, L. and Breakwell, G. M. (2000), "Migration and threat to identity", Journal of Community and Applied Social Psychology, Vol. 10 No. 5, pp. 355-372. https://doi.org/10.1002/1099-1298(200009/10)10:5<355::AID-CASP594>3.0.CO;2-Y

Tung, R. L. (1981), "Selection and training of personnel for overseas assignments", Columbia Journal of World Business, Vol. 16 No. 1, pp. 68-78.

Turner, J. C., Hogg, M. A., Oakes, P. J., Reicher, S. D. and Wetherell, M. S. (1987), Rediscovering the Social Group: A self-categorization Theory, New York: Blackwell.

Valdivia, C. and Flores, L. Y. (2012), "Factors affecting the job satisfaction of Latino/a immigrants in the Midwest", Journal of Career Development, Vol. 39 No. 1, pp. 31-49. https://doi.org/10.1177/0894845310386478

Varma, A., Pichler, S. and Budhwar, P. (2011), "The relationship between expatriate job level and host country national categorization: An investigation in the UK", The International Journal of Human Resource Management, Vol. 22 No. 1, pp. 103-120.

https://doi.org/10.1080/09585192.2011.538971 
Vora, D., Martin, L., Fitzsimmons, S. R., Pekerti, A. A., Lakshman, C. and Raheem, S. (2019), "Multiculturalism within individuals: A review, critique, and agenda for future research", Journal of International Business Studies, Vol. 50 No. 4, pp. 499-524. https://doi.org/10.1057/s41267-018-0191-3

Waibel, S., Aevermann, T. and Rueger, H. (2018), "International mobility and well-being of public sector expatriates: The role of family formation and gender", Journal of Global Mobility, Vol. 6 No. 2, pp. 158-177. https://doi.org/10.1108/JGM-10-2017-0043

Wassermann, M., Fujishiro, K. and Hoppe, A. (2017), “The effect of perceived overqualification on job satisfaction and career satisfaction among immigrants: Does host national identity matter?", International Journal of Intercultural Relations, Vol. 61, pp. 77-87. https://doi.org/10.1016/j.ijintrel.2017.09.001

Willard-Grace, R., Knox, M., Huang, B., Hammer, H., Kivlahan, C. and Grumbach, K. (2019), "Burnout and health care workforce turnover", Annals of Family Medicine, Vol. 17 No. 1, pp. 36-41. https://doi.org/10.1370/afm.2338

Wilk, S. L. and Moynihan, L. M. (2005), “Display rule 'regulators': The relationship between supervisors and worker emotional exhaustion”, Journal of Applied Psychology, Vol. 90, pp. 917927. https://doi.org/10.1037/0021-9010.90.5.917

Wilkinson, A. and Singh, G (2010), "Managing stress in the expatriate family: A case study of the State Department of the United States of America", Public Personnel Management, Vol. 39 No. 2, pp. 169-181. https://doi.org/10.1177/009102601003900206

Wong, S. S. (2016), "Emotions and the communication of intentions in face-to-face diplomacy", European Journal of International Relations, Vol. 22 No. 1, pp.144-167. https://doi.org/10.1177/1354066115581059 
Yuan, K. S., Wu, T. J. and Flynn, M. (2019), “The Influence of Work-Family Conflict on Taiwanese Expatriates' Burnout and Turnover Intention in China: Guanxi as a Moderator”, Revista de Cercetare și Intervenție Socială, Vol. 64, pp. 140-155.

https://doi.org/10.33788/rcis.64.12

Zhang, L. E., Harzing, A. W. and Fan, X. J. (2018), Managing Expatriates in China: A

Language and Identity Perspective, London: Palgrave Macmillan. https://doi.org/10.1057/978-1137-48909-8 
Table 1 Means, standard deviations, and correlations

\begin{tabular}{|c|c|c|c|c|c|c|c|c|c|c|c|c|c|c|}
\hline Variable & $M$ & $S D$ & 1 & 2 & 3 & 4 & 5 & 6 & 7 & 8 & 9 & 10 & 11 & 12 \\
\hline 1. Age & 43.94 & 9.64 & & & & & & & & & & & & \\
\hline 2. Gender & 0.77 & 0.42 & 0.03 & & & & & & & & & & & \\
\hline 3. Living with spouse or partner & 0.67 & 0.47 & 0.01 & $-0.30^{* *}$ & & & & & & & & & & \\
\hline 4. Living with children & 0.48 & 0.50 & -0.13 & $-0.22^{*}$ & $0.44^{* *}$ & & & & & & & & & \\
\hline 5. Number of countries & 4.45 & 2.09 & $0.56^{* *}$ & 0.11 & 0.04 & -0.12 & & & & & & & & \\
\hline 6. Burnout & 2.90 & 0.83 & $-0.19^{*}$ & 0.08 & -0.05 & 0.01 & -0.14 & & & & & & & \\
\hline 7. Home country identification & 5.88 & 1.12 & 0.11 & -0.13 & 0.05 & -0.01 & 0.05 & -0.06 & & & & & & \\
\hline 8. Host country identification & 3.31 & 1.58 & 0.09 & 0.10 & -0.08 & -0.14 & -0.04 & -0.11 & -0.03 & & & & & \\
\hline $\begin{array}{l}\text { 9. Low home and host country } \\
\text { identification }\end{array}$ & 0.19 & 0.39 & -0.17 & 0.06 & 0.07 & $0.21^{*}$ & -0.01 & 0.12 & $-0.40^{* *}$ & $-0.38^{* *}$ & & & & \\
\hline $\begin{array}{l}\text { 10. High home country } \\
\text { identification, low host country } \\
\text { identification }\end{array}$ & 0.34 & 0.48 & 0.03 & -0.10 & 0.00 & -0.01 & 0.04 & 0.13 & $0.40^{* *}$ & $-0.57^{* *}$ & $-0.35^{* *}$ & & & \\
\hline $\begin{array}{l}\text { 11. High host country identification, } \\
\text { low home country identification, }\end{array}$ & 0.17 & 0.38 & -0.10 & 0.09 & 0.05 & -0.00 & -0.17 & -0.05 & $-0.56^{* *}$ & $0.37^{* *}$ & $-0.22^{*}$ & $-0.33^{* *}$ & & \\
\hline $\begin{array}{l}\text { 12. High home and host country } \\
\text { identification }\end{array}$ & 0.30 & 0.46 & $0.20^{*}$ & -0.02 & -0.10 & -0.17 & 0.11 & $-0.19^{*}$ & $0.38^{* *}$ & $0.61^{* *}$ & $-0.31^{* *}$ & $-0.47^{* *}$ & $-0.30^{* *}$ & \\
\hline 13. Satisfaction with own career & 5.38 & 1.12 & -0.00 & -0.01 & -0.00 & 0.07 & -0.01 & $-0.40^{* *}$ & $0.29^{* *}$ & $0.18^{*}$ & $-0.22^{*}$ & 0.04 & -0.06 & $0.20^{*}$ \\
\hline
\end{tabular}

Notes: $\mathrm{n}=123 .{ }^{\mathrm{a}} 0=$ male, $1=$ female. ${ }^{*} p<0.05 .{ }^{* *} p<0.01$. 
Table 2 Diplomats host country information

\begin{tabular}{|c|c|c|c|c|}
\hline & & Host country & Frequency & Percent \\
\hline \multirow[t]{28}{*}{ Valid } & 1 & Angola & 1 & 0.8 \\
\hline & 2 & Argentina & 1 & 0.8 \\
\hline & 3 & Australia & 3 & 2.4 \\
\hline & 4 & Austria & 5 & 4.1 \\
\hline & 5 & Belgium & 11 & 8.9 \\
\hline & 6 & Bosnia and Herzegovina & 1 & 0.8 \\
\hline & 7 & China & 5 & 4.1 \\
\hline & 8 & Costa Rica & 1 & 0.8 \\
\hline & 9 & $\begin{array}{l}\text { Croatia } \\
\text { Democratic Republic of the }\end{array}$ & 1 & 0.8 \\
\hline & 10 & Congo & 1 & 0.8 \\
\hline & 11 & Denmark & 1 & 0.8 \\
\hline & 12 & Egypt & 2 & 1.6 \\
\hline & 13 & Estonia & 1 & 0.8 \\
\hline & 14 & Ethiopia & 3 & 2.4 \\
\hline & 15 & Finland & 1 & 0.8 \\
\hline & 16 & France & 2 & 1.6 \\
\hline & 17 & Germany & 2 & 1.6 \\
\hline & 18 & Greece & 2 & 1.6 \\
\hline & 19 & Guatemala & 1 & 0.8 \\
\hline & 20 & Honduras & 1 & 0.8 \\
\hline & 21 & Hong Kong (S.A.R.) & 1 & 0.8 \\
\hline & 22 & India & 4 & 3.3 \\
\hline & 23 & Iran, Islamic Republic of... & 2 & 1.6 \\
\hline & 24 & Israel & 3 & 2.4 \\
\hline & 25 & Italy & 1 & 0.8 \\
\hline & 26 & Japan & 8 & 6.5 \\
\hline & 27 & Kazakhstan & 1 & 0.8 \\
\hline & 28 & Kenya & 4 & 3.3 \\
\hline
\end{tabular}

\begin{tabular}{|c|c|c|c|c|}
\hline & 29 & Latvia & 2 & 1.6 \\
\hline & 30 & Lebanon & 1 & 0.8 \\
\hline & 31 & Lithuania & 1 & 0.8 \\
\hline & 32 & Luxembourg & 1 & 0.8 \\
\hline & 33 & Malaysia & 1 & 0.8 \\
\hline & 34 & Mexico & 2 & 1.6 \\
\hline & 35 & Morocco & 1 & 0.8 \\
\hline & 36 & Nepal & 1 & 0.8 \\
\hline & 37 & Netherlands & 2 & 1.6 \\
\hline & 38 & New Zealand & 1 & 0.8 \\
\hline & 39 & Poland & 2 & 1.6 \\
\hline & 40 & Republic of Korea & 1 & 0.8 \\
\hline & 41 & Romania & 1 & 0.8 \\
\hline & 42 & Russian Federation & 5 & 4.1 \\
\hline & 43 & Saudi Arabia & 1 & 0.8 \\
\hline & 44 & Singapore & 1 & 0.8 \\
\hline & 45 & South Africa & 3 & 2.4 \\
\hline & 46 & Spain & 1 & 0.8 \\
\hline & 47 & Sweden & 2 & 1.6 \\
\hline & 48 & Switzerland & 2 & 1.6 \\
\hline & 49 & Ukraine & 4 & 3.3 \\
\hline & 50 & $\begin{array}{l}\text { United Arab Emirates } \\
\text { United Kingdom of Great }\end{array}$ & 3 & 2.4 \\
\hline & 51 & Britain and Northern Ireland & 2 & 1.6 \\
\hline & 52 & United States of America & 8 & 6.5 \\
\hline & 53 & Viet Nam & 1 & 0.8 \\
\hline Missing & & Other & 3 & 2.4 \\
\hline Total & & & 123 & 100 \\
\hline
\end{tabular}


Table 3 Regression Results

\begin{tabular}{|c|c|c|c|c|c|c|c|c|c|c|c|}
\hline & \multicolumn{11}{|c|}{ Dependent variable: Career satisfaction } \\
\hline & Model 1 & Model 2 & Model 3 & Model 4 & Model 5 & Model 6 & Model 7 & Model 8 & Model 9 & Model 10 & Model 11 \\
\hline & $b(S E)$ & $b(S E)$ & $b(S E)$ & $b(S E)$ & $b(S E)$ & $b(S E)$ & $b(S E)$ & $b(S E)$ & $b(S E)$ & $b(S E)$ & $b(S E)$ \\
\hline Age & $0.00(0.01)$ & $-0.01(0.01)$ & $0.00(0.01)$ & $0.00(0.01)$ & $-0.00(0.01)$ & $-0.01(0.01)$ & $-0.01(0.01)$ & $-0.01(0.01)$ & $-0.01(0.01)$ & $-0.01(0.01)$ & $-0.01(0.01)$ \\
\hline Gender $^{\mathrm{a}}$ & $-0.02(0.26)$ & $0.08(0.24)$ & $-0.01(0.26)$ & $0.00(0.26)$ & $0.03(0.26)$ & $0.10(0.26)$ & $0.20(0.24)$ & $0.24(0.24)$ & $0.20(0.24)$ & $0.18(0.23)$ & $0.17(0.24)$ \\
\hline $\begin{array}{l}\text { Living with spouse or } \\
\text { partner }\end{array}$ & $-0.11(0.25)$ & $-0.13(0.23)$ & $-0.11(0.25)$ & $-0.09(0.25)$ & $-0.08(0.25)$ & $-0.06(0.24)$ & $-0.08(0.23)$ & $-0.10(0.22)$ & $-0.08(0.23)$ & $-0.06(0.22)$ & $-0.06(0.22)$ \\
\hline \multicolumn{12}{|l|}{ Living with children under } \\
\hline 18 & $0.21(0.23)$ & $0.22(0.21)$ & $0.21(0.23)$ & $0.21(0.23)$ & $0.28(0.23)$ & $0.36(0.23)$ & $0.34(0.21)$ & $0.34(0.21)$ & $0.33(0.21)$ & $0.30(0.21)$ & $0.32(0.21)$ \\
\hline Number of countries & $-0.00(0.06)$ & $-0.02(0.06)$ & $-0.00(0.06)$ & $-0.01(0.06)$ & $-0.00(0.06)$ & $0.01(0.06)$ & $-0.01(0.06)$ & $-0.02(0.05)$ & $-0.01(0.05)$ & $-0.03(0.05)$ & $-0.03(0.05)$ \\
\hline Burnout & & $-0.56^{* * *}(0.12)$ & & & & & $-0.54^{* * *}(0.12)$ & $-0.53^{* * *}(0.12)$ & $-0.54^{* * *}(0.12)$ & $-0.52^{* * *}(0.11)$ & $-0.93^{* *}(0.28)$ \\
\hline \multicolumn{12}{|l|}{ High home country } \\
\hline \multicolumn{12}{|l|}{ identification, low-host } \\
\hline country identification ${ }^{\mathrm{b}}$ & & & $0.09(0.22)$ & & & $0.68^{*}(0.30)$ & $0.68^{*}(0.27)$ & $0.72^{* *}(0.27)$ & $0.68^{*}(0.27)$ & $0.64^{*}(0.26)$ & $-0.11(1.08)$ \\
\hline \multicolumn{12}{|l|}{ High host country } \\
\hline \multicolumn{12}{|l|}{ identification, low-home } \\
\hline country identification & & & & $-0.19(0.28)$ & & $0.44(0.34)$ & $0.27(0.32)$ & $0.29(0.32)$ & $0.26(0.32)$ & $0.18(0.31)$ & $-0.88(1.18)$ \\
\hline \multicolumn{12}{|l|}{ High home and } \\
\hline hostcountry identification & & & & & $0.54^{*}(0.23)$ & $1.01^{* *}(0.31)$ & $0.81^{* *}(0.29)$ & $0.85^{* *}(0.29)$ & $0.81^{* *}(0.29)$ & $0.85^{* *}(0.28)$ & $-1.72(1.07)$ \\
\hline \multicolumn{12}{|l|}{ Burnout * High home } \\
\hline \multicolumn{12}{|l|}{ country identification, low } \\
\hline host country identification & & & & & & & & $-0.27(0.24)$ & & & $0.25(0.34)$ \\
\hline \multicolumn{12}{|l|}{ Burnout * High host } \\
\hline \multicolumn{12}{|l|}{ country identification, low } \\
\hline \multicolumn{12}{|l|}{ home country } \\
\hline identification & & & & & & & & & $-0.02(0.31)$ & & $0.36(0.39)$ \\
\hline \multicolumn{12}{|l|}{ Burnout * High home and } \\
\hline host country identification & & & & & & & & & & $0.66^{* *}(0.25)$ & $0.87^{*}(0.35)$ \\
\hline $\mathrm{R}^{2}$ & 0.01 & 0.17 & 0.01 & 0.01 & 0.05 & 0.10 & 0.24 & 0.25 & 0.24 & 0.29 & 0.29 \\
\hline $\mathrm{F}$ & 0.17 & 4.03 & 0.17 & 0.22 & 1.08 & 1.50 & 3.98 & 3.72 & 3.55 & 4.48 & 3.77 \\
\hline
\end{tabular}

Notes: $\mathrm{n}=123 .{ }^{\mathrm{a}} 0=\operatorname{man}, 1=$ woman. ${ }^{\mathrm{b}}$ Reference category: low home and

host country identification. ${ }^{*} p<0.05 .{ }^{* *} p<0.01 .{ }^{* * *} p<0.001$. 
Figure 1 Effect of the interaction between burnout and home country/host country identification on career satisfaction

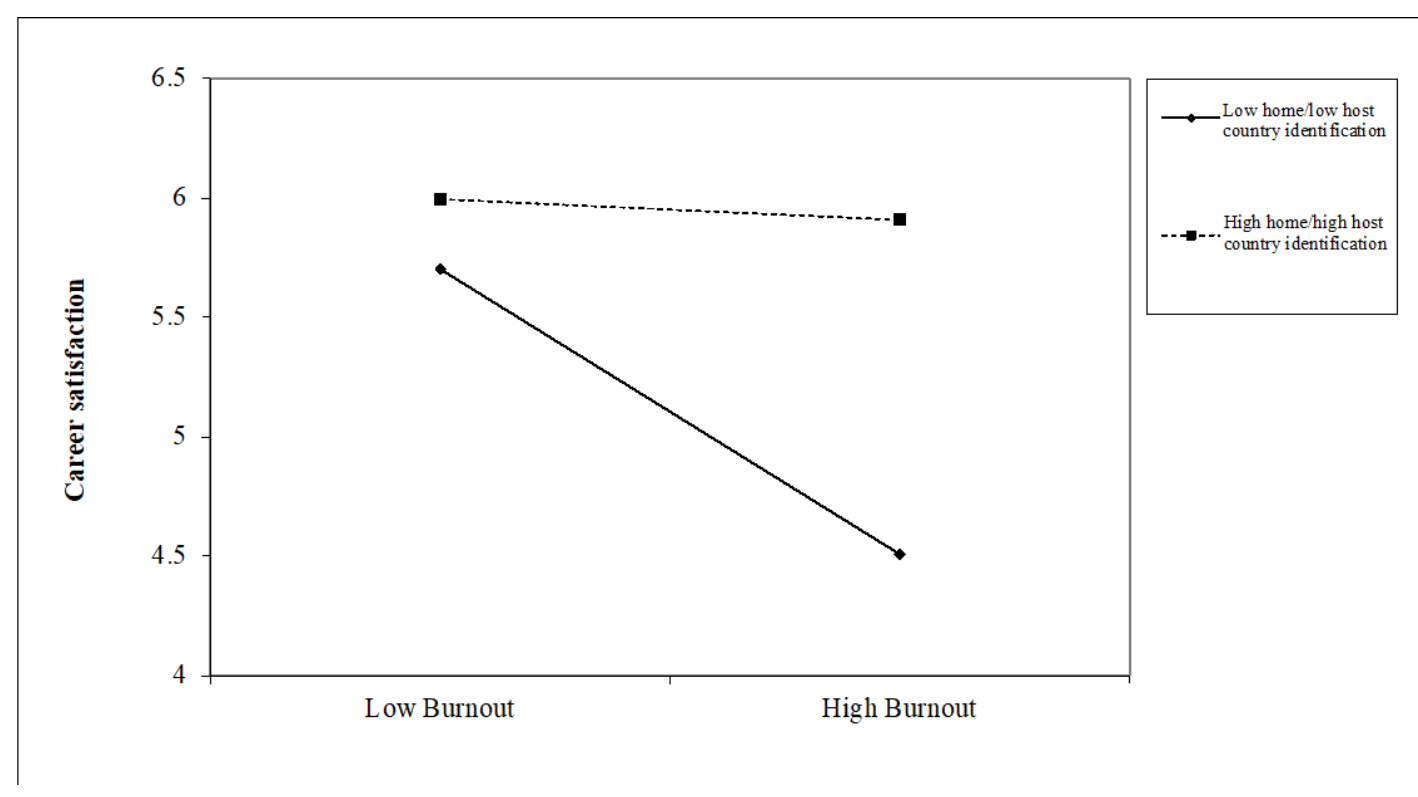

